\title{
Current recommendations regarding the management of juvenile dermatomyositis
}

On the basis of: Enders F.B., Bader-Meunier B., Baildam E. et al. Consensus-based recommendations for the management of juvenile dermatomyositis. Ann. Rheum. Dis. 2017; 76 (2): 329-340.

\section{ABBREVIATIONS}

\author{
ADA - Adalimumab \\ ANA - Antinuclear antibodies \\ CAT - Cutaneous Assessment Tool, \\ CHAQ - Childhood Health Assessment Questionnaire \\ CHQ - Childhood Health Questionnaire \\ CMAS - Childhood Myositis Assessment Scale \\ CsA - Ciclosporin A \\ CYC - Cyclophosphamide \\ DAS - Disease Activity Score \\ DLCO - diffusing capacity of the lung for carbon monoxide \\ ETN - Etanercept \\ GCC - Glucocorticoids \\ HRCT - High-resolution computed tomography \\ INF - Infliximab \\ IVIG - Intravenous immunoglobulin \\ JDMAR - Juvenile Dermatomyositis Multi-dimensional Assessment Report \\ MDI - Myositis Damage Index \\ MITAX - Myositis intention to treat activity index, \\ MMF - Mycophenolate mofetil \\ MMT 8 - Manual Muscle Testing Procedures for MMT8 Testing \\ JRD - Juvenile rheumatic diseases \\ MRI — Magnetic Resonance Imaging \\ MTX - Methotrexate \\ JDM - Juvenile dermatomyositis \\ VAS - Visual Analogue Scale
}

\section{INTRODUCTION}

Juvenile dermatomyositis (JDM) is a rare disease in the group of rheumatic diseases in children. However, due to its potentially severe course it may lead to a significant reduction in the quality of life. Evidence-based guidelines are scarce, and comprehensive care is mainly based on the knowledge and experience of teams of clinicians. So far, no uniform rules of procedure, diagnosis and treatment have been developed for skin and muscle inflammation in children. The existing patterns of comprehensive care and treatment differ significantly across Europe.

In 2012, an initiative was launched in the field of paediatric rheumatology in Europe
Address for correspondence: dr hab. $n$ med. Zbigniew Żuber, prof. nadzw.

Department of Older Children with Subunits of Neurology and Rheumatology

St. Louis Children's Hospital

ul. Strzelecka 2

31-503 Kraków

tel.: +48126198630

fax: + 48126198681

e-mail: zbyszekzuber@interia.pl 
(SHARE), aimed at optimising and disseminating diagrams of diagnostics, treatment and comprehensive care for children and adolescents with rheumatic diseases.

The SHARE initiative aims to develop and disseminate the best practices in the diagnosis of treatment of patients suffering from juvenile rheumatic diseases (JRD).

As part of this program, recommendations regarding the comprehensive care for patients with JDM have been formulated based on an evidence-based process of agreeing uniform recommendations that form the basis for creating a standard of care for those affected by JDM throughout Europe.

Juvenile dermatomyositis (JDM) is the most common idiopathic inflammatory myopathy in developmental age, with the incidence being low $-2-4$ cases per one million children per year. Standardisation of diagnostic tests and treatment patterns will allow joint research focused on increasing knowledge about this rare disease. Vasculopathy in the course of JDM mainly affects the muscles and skin, but may affect other organs and may cause systemic symptoms. If treatment is provided in the early stage of the disease, in $30-50 \%$ of patients there is a possibility of achieving remission within 2-3 years from the onset of disease symptoms with minor complications and mortality below $4 \%$.

The recurrent or persistently active form of the disease affects $40-60 \%$ of patients (according to data from recent multi-centre cohort studies, depending on the activity measures used) and the presence of complications such as: calcinosis, persistent muscle weakness, skin and/or muscle atrophy; in these cases, the prognosis remains problematic.

The risk of lipodystrophy and calcinosis is associated with a longer period of disease activity and insufficient response to the initial GCC-based treatment. The quality of life can be significantly worse compared to healthy peers, both in the physical and psychosocial sphere, and subsequently psychosocial support is required. Due to the rare occurrence and usually severe course of the disease, it was found that children suffering from JDM should be cared for in specialised centres with experience and knowledge in this area.

The recommendations have been developed based on an evidence-based consensus process using standard EULAR operational procedures. A committee consisting of 19 experienced paediatric rheumatologists and
2 experts in the field of physiology and physiotherapy was established.

The recommendations were derived from an approved systematic review of the literature, data was evaluated using an online survey and then discussed at two consensus meetings with the use of the nominal group technique.

The recommendations were accepted if an agreement of more than $80 \%$ was reached.

In total, 7 overarching principles, 33 recommendations regarding diagnosis and 19 recommendations regarding treatment were adopted, with the opinion compliance of experts of over $80 \%$.

These recommendations include assessment of the skin, muscles and internal organs, as well as suggested treatment pathways.

\section{OVERARCHING PRINCIPLES FOR JDM}

1. All children with suspected JDM should be referred to a specialised centre.

2. For JDM, patient-/parent-reported outcome measures are helpful when assessing disease activity and should be used at diagnosis and during disease monitoring.

3. Validated tools should be used to measure health status, for example, the Childhood Health Assessment Questionnaire, patient/parent visual analogue scale, Childhood Health Questionnaire, Juvenile Dermatomyositis Multi-dimensional Assessment Report.

4. All children with JDM should have disease activity (muscle, skin, major organ) assessed regularly in a standardised way, using tools such as the Disease Activity Score.

5. All children with JDM should have disease damage assessed at least yearly using a standardised disease damage measure, such as the Myositis Damage Index.

6. All patients with JDM should have the opportunity to be registered within a national/international research registry/repository, for example, the Euromyositis registry.

7. High-risk patients need immediate/urgent referral to a specialised centre.

High risk patients are defined by:

— severe disability, defined by inability to get off bed;

- CMAS score < 15, or MMT8 score < 30;

- presence of aspiration or dysphagia (to the point of inability to swallow);

- gastrointestinal vasculitis (as determined by imaging or presence of bloody stools); 
- myocarditis;

- parenchymal lung disease;

- central nervous system disease (defined as decreased level of consciousness or seizures);

- skin ulceration;

- requirement for intensive care unit management;

- age $<1$ year.

\section{RECOMMENDATIONS REGARDING DIAGNOSIS}

\section{A. General recommendations}

In the absence of cutaneous signs and/or failure to respond as expected to therapy, alternative diagnoses should be considered including metabolic or mitochondrial myopathies and dystrophies.

In every patient in whom a diagnosis of JDM is considered, the following list of investigations should be considered:

- Muscle enzymes - including creatinine phosphokinase (CPK), LDH, AST (SGOT), ALT (SGPT), adolase (if available);

- Full blood count and blood film;

- ESR (or plasma viscosity) and CRP;

- Myositis-specific and myositis-associated antibodies;

- Renal function and liver function tests;

- Infection screen (for differential diagnosis);

- Investigations for alternative systemic causes of myopathy including endocrine disorders (especially thyroid function), electrolyte disturbances, vitamin D deficiency;

- Further tests for metabolic/mitochondrial myopathies (especially in the absence of rash/atypical presentation);

- Urine dipstick (with further evaluation if positive for protein);

- Nailfold capillaroscopy;

- Echocardiogram and ECG;

- Pulmonary function tests (chest X-ray and HRCT if concern);

- MRI of muscles (+quantitative ultrasound);

- EMG (particularly if suspicion of neuropathy/disorder of neuromuscular junction);

- Muscle biopsy (especially in the absence of rash/atypical presentation);

- MRI brain if neurological involvement suspected;

- Abdominal ultrasound scan.

B. Specific recommendations Assessment of muscle involvement

- Both muscle strength and function should be tested at diagnosis and follow up by formal validated measures, such as the MMT8 andthe CMAS.

- MRI can be used to aid diagnosis of JDM.

- MRI can be used to help monitor disease activity

- When used, MRI should be carried out by defined protocols that enhance detection of muscle inflammation, such as T2 weighted/STIR sequences.

- MRI should be interpreted by an expert radiologist.

- A muscle biopsy should be done in all cases where the presentation of JDM is atypical; in particular in the absence of rash/skin signs.

- If a muscle biopsy is performed for diagnosis of JDM, a standardised JDM biopsy score tool should be used to quantify severity of histological abnormalities.

- Expert histopathological opinion is required to define features of inflammation in JDM muscle biopsy.

- When doing a muscle biopsy, there is insufficient evidence to recommend a needle biopsy as opposed to an open biopsy in children.

- In cases where MRI or muscle biopsy is not possible, increased muscle echo intensity on muscle ultrasonography (when performed by an experienced sonographer) may be indicative of myositis.

- Swallow function should be formally assessed in every patient. The assessment may include a speech and language therapy assessment, video fluoroscopy/barium studies.

- EMG or nerve conduction velocity should be considered to differentiate myopathy from neuropathy when diagnosis of JDM is uncertain.

- EMG does not detect metabolic myopathies reliably and further workup is required if this diagnosis is suspected.

\section{ASSESSMENT OF SKIN INVOLVEMENT}

- Assessment of nailfold capillaries should be used to aid diagnosis of JDM.

- At time of diagnosis or disease flare, standardised nailfold capillaroscopy assessment is recommended. During follow-up, assessment of nailfold capillaries should be performed regularly.

- A formal CAT should be used to aid diagnosis of JDM.

- A formal CAT should be used to monitor skin disease activity over time.

- Skin tools may include the DAS (skin), MITAX (skin) or CAT. 


\section{ASSESSMENT OF LUNG INVOLVEMENT}

- All patients with JDM should have an assessment of lung involvement at time of diagnosis.

- Assessment should include pulmonary function tests, including $\mathrm{CO}$ diffusion. If pulmonary function tests are indicative of interstitial lung disease, further investigations (CXR/HRCT) are needed.

\section{ASSESSMENT OF CARDIAC INVOLVEMENT}

- All patients with JDM should have echocardiography and ECG at diagnosis.

- Patients at particular risk of cardiac dysfunction should have repeated cardiac evaluation.

- Risk factors include hypertension, high disease activity 1 year post diagnosis, long-term high corticosteroid burden or chronic ongoing active disease.

\section{ASSESSMENT OF CALCINOSIS}

- Calcinosis should be looked for in all patients with JDM.

- Plain radiographs may be used for the evaluation of calcinosis.

\section{AUTOANTIBODIES AND BIOMARKERS}

- We recommend use of muscle enzymes (CPK, LDH, AST) for diagnosis and disease monitoring in JDM, although it must be recognised muscle enzymes may be normal despite active disease.

- Measurement of von Willebrand factor does not provide any additional information for diagnosis of JDM.

- There is no significant diagnostic benefit gained from measurement of antinuclear antibody in JDM.

- Further validation studies are recommended to define the use of more sensitive biomarkers in JDM.

- Measurement of myositis-specific autoantibodies (such as anti-TIF 1- $\gamma$ (p155), anti-NXP2/(p140/MJ), anti-MDA5 and anti-SRP) should be considered, when available.

- In patients with overlap features, measurement of myositis-associated-antibodies such as anti-PmScl, anti-U1-RNP, anti-La ('SSB'), anti-Ro ('SSA') and anti-Sm may be helpful to clarify the diagnosis.

\section{RECOMMENDATIONS REGARDING TREATMENT}

- Sun protection, including the routine use of sunblock on sun-exposed areas should be encouraged for patients with JDM
- When treating patients with JDM, it is particularly important to have a physiotherapist and a specialist nurse actively involved as part of a multidisciplinary team.

- Treatment of JDM should include a safe and appropriate exercise programme, monitored by a physiotherapist.

- We recommend the induction regimen for treatment of new onset patients with JDM to be based on high dose of corticosteroids (oral or intravenous) combined with MTX.

- High-dose corticosteroids should be administered systemically either orally or intravenously in moderate-severe JDM.

- High-dose corticosteroids should be administered intravenously if there are concerns about absorption.

- Corticosteroid dose should be weaned as the patient shows clinical improvement.

- Addition of MTX or ciclosporin A leads to better disease control than prednisolone alone; safety profiles favour the combination of methotrexate and prednisolone.

- MTX should be started at a dose of 15$20 \mathrm{mg} / \mathrm{m} 2 /$ week (max absolute dose of $40 \mathrm{mg} /$ week) preferably administered subcutaneously at disease onset.

- If a newly diagnosed patient has inadequate response to treatment, intensification of treatment should be considered within the first 12 weeks, after consultation with an expert centre.

- Intravenous immunoglobulin may be a useful adjunct for resistant disease, particularly when skin features are prominent.

- MMF may be a useful therapy for muscle and skin disease (including calcinosis).

- Ongoing skin disease reflects ongoing systemic disease and therefore should be treated by increasing systemic immunosuppression.

- Topical tacrolimus $(0.1 \%)$ /topical steroids may help localised skin disease, particularly for symptomatic redness or itching.

- In patients who are intolerant to methotrexate, change to another DMARD, including ciclosporin A or MMF.

- For patients with severe disease (such as major organ involvement/extensive ulcerative skin disease), addition of intravenous cyclophosphamide should be considered.

- Anti-TNF therapies can be considered in refractory disease; infliximab or adalimumab are favoured over etanercept.

- In the presence of developing or established calcinosis, intensification of im- 


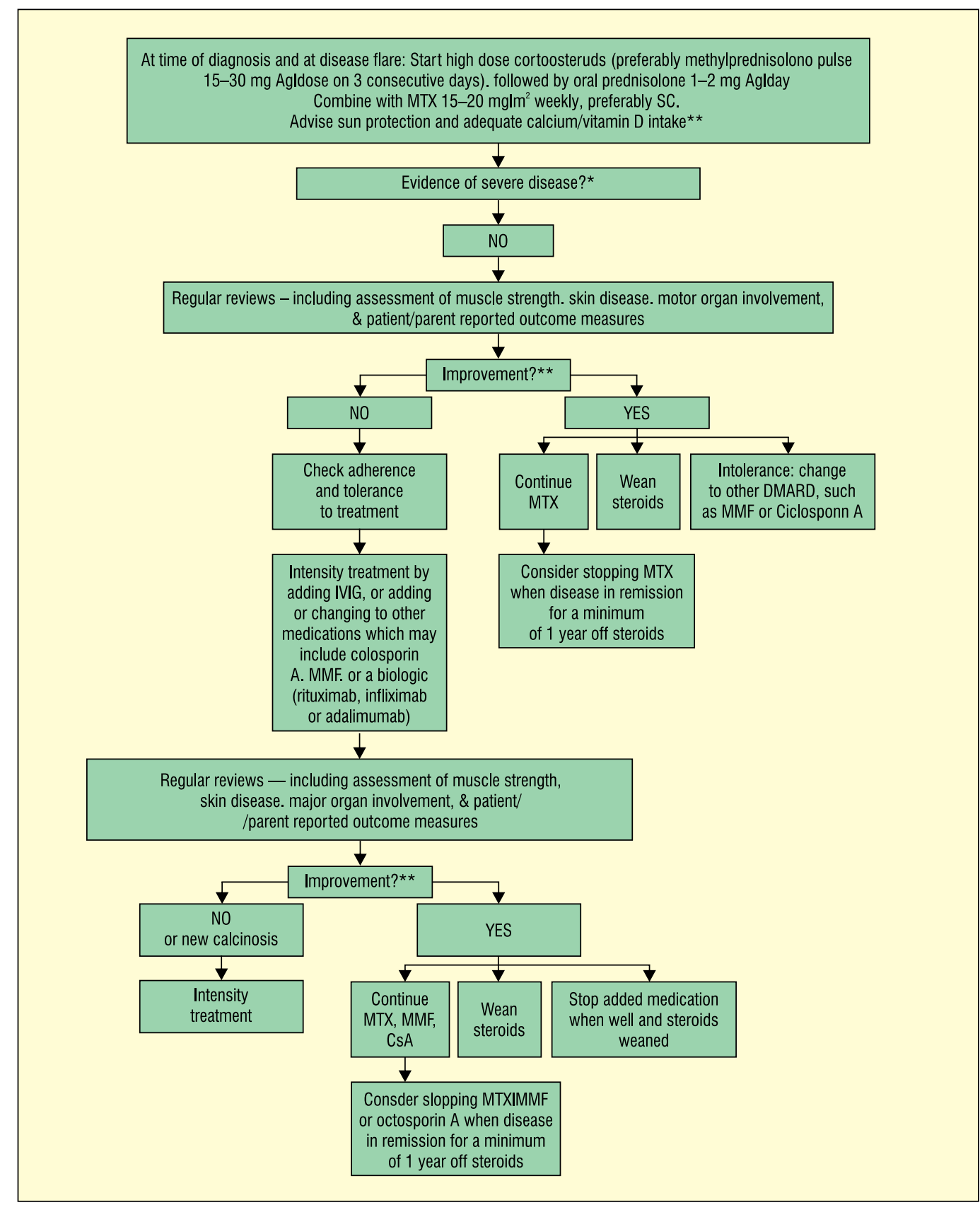

Figure 1. Scheme of treatment of mild/moderate disease in the newly diagnosed and the GCC preliminary treatment-resistant patients with the juvenile dermatomyositis (JDM)

munosuppressive therapy should be considered.

- There is no high-level evidence of when to stop therapy; however, consideration may be given to withdrawing treatment if a patient has been off steroids and in remission on methotrexate (or alternative DMARD) for a minimum of 1 year.

- B cell depletion therapy (rituximab) can be considered as an adjunctive therapy for those with refractory disease. Clinicians should be aware that rituximab can take up to 26 weeks to work (Fig. 1, 2).

\section{CONCLUSIONS}

Close monitoring of patients' health and well-being by an experienced, multidisciplinary team is essential for a good clinical result. Recent reports emphasise the importance of early, aggressive treatment of JDM, because it is associated with better control of the disease course. Due to the low incidence of disease, long-term multi-centre controls are necessary to explain the risk of complications and the international cooperation is of key importance. Further research and studies are needed regarding the 


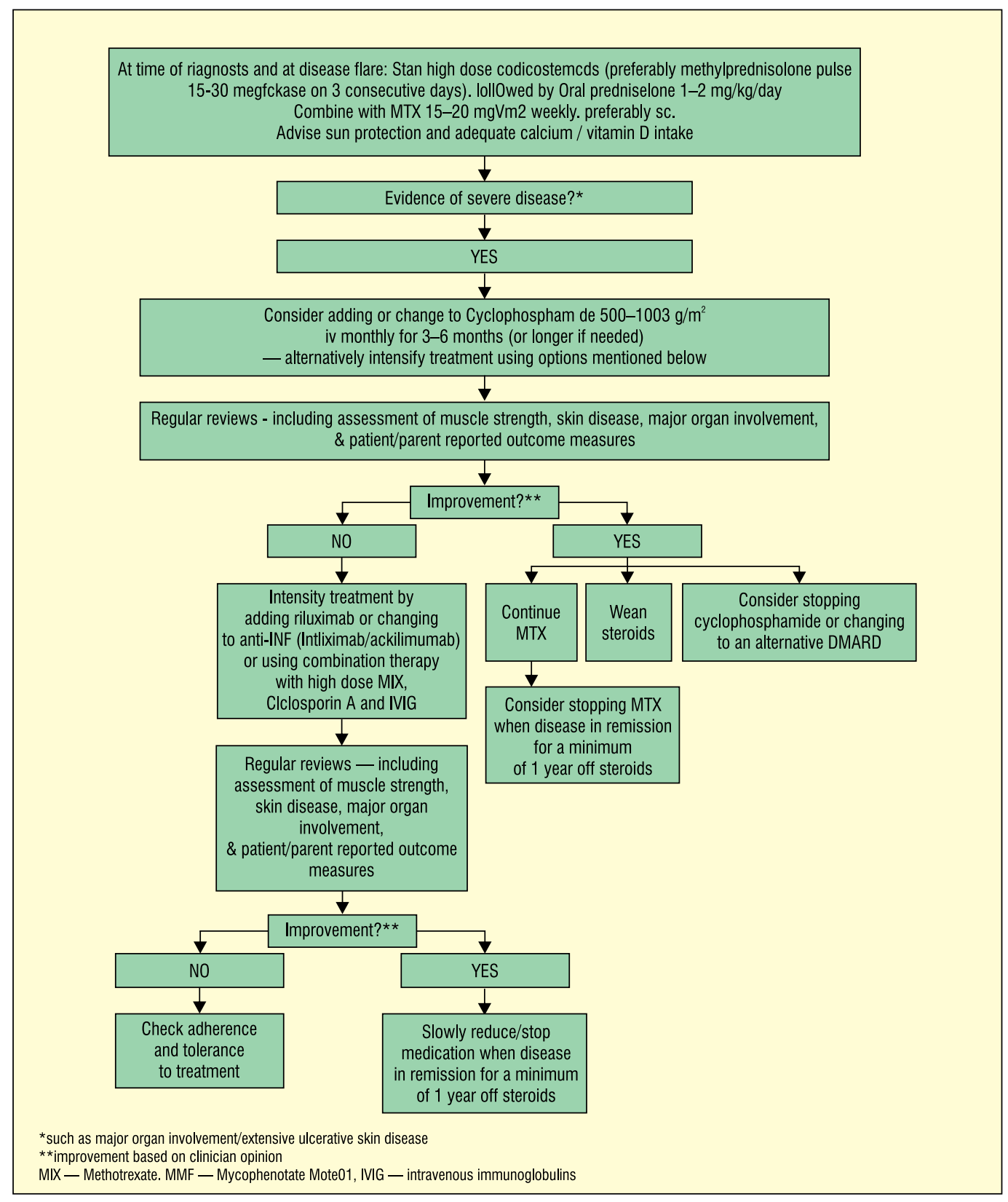

Figure 2. Scheme of the severe disease treatment in the newly diagnosed patients and in cases of ineffective treatment of patients suffering from JDM

activity of the disease, its course, threatening complications and its long-term consequences.

In summary, the SHARE initiative is based on expert opinions based on the best available evidence and it includes recommendations for diagnosis, treatment and overall care for the JDM patients, aiming to improve the treatment results of patients with JDM across
Europe. The SHARE initiative also includes other rheumatic diseases in children, being a platform for an ongoing cooperation in all European countries. It is currently of great significance to broaden the discussion and test acceptance of the recommendations presented for the broad community of European paediatric rheumatologists.

\section{References}

1. Enders FB, Bader-Meunier B, Baildam E, et al. Consensus-based recommendations for the management of juvenile dermatomy- ositis. Ann Rheum Dis. 2017; 76(2): 329-340, doi: 10.1136/annrheumdis-2016-209247, indexed in Pubmed: 27515057. 


\section{Zbigniew Żuber}

Katedra Pediatrii, Krakowska Akademia im. Andrzeja Frycza Modrzewskiego, Kraków Oddział Dzieci Starszych z pododdziałami Neurologii i Reumatologii, Szpital Dziecięcy św. Ludwika, Kraków

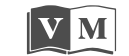

VIA MEDICA

www.fr.viamedica.pl

\section{Aktualne rekomendacje dotyczace postepowania w młodzieńczym zapaleniu skórno-mięśniowym}

Opracowano na podstawie: Enders F.B., Bader-Meunier B., Baildam E. i wsp. Consensus-based recommendations for the management of juvenile dermatomyositis. Ann. Rheum. Dis. 2017; 76 (2): 329-340.

Artykuł jest tłumaczeniem pracy: Żuber Z. Current recommendations regarding the management of juvenile dermatomyositis. Forum Reumatol. 2018; tom 4, nr 4: 199-204.

Należy cytować wersję pierwotną.

Piśmiennictwo znajduje się na stronie 204

\section{SKRÓTY}

ADA - adalimumab

ANA - przeciwciała przeciwjądrowe

CAT - Cutaneous Assessment Tool

CHAQ - Childhood Health Assessment Questionnaire

CHQ - Childhood Health Questionnaire

CMAS - dziecięca skala oceny mięśni

CsA - cyklosporyna A

CYC - cyklofosfamid

DAS (Disease Activity Score) — wskaźnik aktywności choroby

DLCO — zdolność dyfuzyjna

ETN - etanercept

GKS - glukortykosteroidy

HRCT - tomografia komputerowa wysokiej rozdzielczości

INF — inflixymab

IVIG — immunoglobuliny podawane dożylnie

JDMAR — Juvenile Dermatomyositis Multi-dimensional Assessment Report

MDI (Myositis Damage Index) — wskaźnik uszkodzenia mięśni

MITAX - myositis intention to treat activity index

MMF - mykofenolan mofetylu

MMT 8 (Manual Muscle Testing Procedures For MMT8 Testing) — manualny test 8 mięśni

MPChR - młodzieńcze postaci chorób reumatycznych

MRI - rezonans magnetyczny

MTX - methotreksat

MZSM (JDM, juvenile dermatomyositis) — młodzieńcze zapalenie skórno-mięśniowe

VAS - wizualna skala analogowa

\section{WSTĘP}

Młodzieńcze zapalenie skórno-mięśniowe (MZSM) to rzadko spotykana choroba w grupie chorób reumatycznych u dzieci, jednak ze względu na potencjalnie ciężki przebieg może prowadzić do znacznego obniżenia jakości życia. Wytyczne oparte na dowodach są nieliczne, kompleksowa opieka opiera się głównie na wiedzy i doświadczeniach zespołów lekarzy klinicystów. Dotychczas nie było opracowanych jednolitych zasad postępowania, diagnostyki i leczenia w przypadkach wystąpienia zapaleni skórno-mięśniowego u dzieci. Dotychczasowe schematy kompleksowej opieki i leczenia różnią się istotnie w całej Europie.

W 2012 roku podjęto inicjatywę w zakresie reumatologii dziecięcej w Europie (SHA-
Adres do korespondencji: dr hab. n med. Zbigniew Żuber, prof. nadzw.

Oddział Dzieci Starszych z Poddziałami Neurologii i Reumatologii Szpitala Dziecięcego św. Ludwika w Krakowie ul. Strzelecka 2 31-503 Kraków tel.: +481261986 30 faks: + 48126198681 e-mail: zbyszekzuber@interia.pl 
RE), mającą na celu optymalizację i rozpowszechnienie schematów diagnostyki, leczenia oraz kompleksowej opieki nad dziećmi i młodzieżą z chorobami reumatycznymi.

Inicjatywa SHARE ma na celu opracowanie i rozpropagowanie najlepszych praktyk w diagnostyce leczeniu pacjentów cierpiących na młodzieńcze postaci chorób reumatycznych (MPChR).

W ramach tego programu zalecenia dotyczące kompleksowej opieki na chorującymi na MZSM zostały sformułowane w oparciu o oparty na dowodach, proces uzgadniania jednolitych zaleceń będących podstawą stworzenia standardu opieki nad chorującymi na MZSM w całej Europie.

Młodzieńcze zapalenie skórno-mięśniowe (MZSM) jest najczęstszą idiopatyczną miopatią zapalną w wieku rozwojowym, częstość jej występowania jest niska, 2-4 przypadków na milion dzieci rocznie. Standaryzacja testów diagnostycznych i schematów leczenia pozwoli na wspólne badania naukowe w celu zwiększenia wiedzy na temat tej rzadkiej choroby. Waskulopatia w przebiegu MZSM wpływa głównie na mięśnie i skórę, ale może wpływać na inne narządy, może powodować objawy ogólnoustrojowe. W przypadku wdrożenie leczenia we wczesnym okresie choroby, u 30-50\% pacjentów istnieje możliwość uzyskania remisji w ciągu 2-3 lat od wystąpienia objawów choroby z niewielkimi powikłaniami i śmiertelnością poniżej $4 \%$.

Nawrotowa lub uporczywie aktywna postać choroby dotyka 40-60\% pacjentów (zgodnie $\mathrm{z}$ danymi $\mathrm{z}$ ostatnich wieloośrodkowych badań kohortowych, w zależności od zastosowanych miar aktywności) oraz obecnością powikłań, takich jak: wapnica, utrzymujące się osłabienie mięśni, zaniki skóry i/lub mięśni, w tych przypadkach rokowanie pozostaje problematyczne.

Ryzyko lipodystrofii i wapnicy jest związane z dłuższym czasem aktywności choroby i niewystarczającą odpowiedzią na wstępną terapię glikokortykosteroidami (GKS). Jakość życia może być wyraźnie gorsza w porównaniu ze zdrowymi rówieśnikami zarówno w sferze fizycznej, jak i psychospołecznej, wtedy wymagane jest wsparcie psychospołeczne. W związku z rzadkim występowaniem i z reguły ciężkim przebiegiem choroby ustalono, że dzieci chorujące na MZSM powinny być otoczone opieką w specjalistycznych ośrodkach posiadających doświadczenie i wiedzę w tym zakresie.
Zalecenia opracowano na podstawie, opartego na dowodach, procesu konsensusu, wykorzystującego standardowe procedury operacyjne EULAR. Utworzono komitet składający się z 19 doświadczonych reumatologów dziecięcych oraz 2 ekspertów $z$ dziedziny fizjologii i fizjoterapii.

Zalecenia wyprowadzono $\mathrm{z}$ zatwierdzonego systematycznego przeglądu literatury, dane oceniano za pomocą ankiety internetowej, a następnie omawiano na dwóch spotkaniach konsensusowych z zastosowaniem techniki grup nominalnych.

Zalecenia zostały zaakceptowane, jeżeli osiągnięto porozumienie na poziomie powyżej $80 \%$. Łącznie przyjęto 7 nadrzędnych zasad, 33 zalecenia dotyczące diagnostyki oraz 19 zaleceń dotyczących terapii, przy zgodności opinii ekspertów powyżej 80\%.

Zalecenia obejmują ocenę skóry, mięśni i narządów wewnętrznych, przedstawiono także sugerowane ścieżki leczenia.

\section{NADRZĘNE ZASADY DOTYCZACE MZSM}

1. Każde dziecko z podejrzeniem MZSM powinno być skierowane do specjalistycznego ośrodka.

2. W przypadku MZSM ocena przebiegu choroby (VAS) przez pacjenta/rodzica jest pomocna przy ocenie aktywności choroby i powinna być stosowana podczas diagnostyki i monitorowania choroby.

3. Zatwierdzone narzędzia powinny być wykorzystywane do pomiaru stanu zdrowia, na przykład CHAQ (Childhood Health Assessment Questionnaire), VAS pacjenta/rodzica, CHQ (Childhood Health Questionnaire), JDMAR (Juvenile Dermatomyositis Multi-dimensional Assessment Report).

4. Wszystkie dzieci z MZSM powinny mieć regularnie ocenią aktywność choroby (mięśni, skóry, głównych narządów) w sposób wystandaryzowany, stosując takie narzędzia, jak wskaźnik aktywności choroby (DAS, Disease Activity Score).

5. Wszystkie dzieci z MZSM powinny mieć oceniane trwałe uszkodzenia $\mathrm{w}$ przebiegu choroby co najmniej raz w roku przy użyciu znormalizowanego kwestionariusza, takiego jak wskaźnik uszkodzenia mięśni (MDI, Myositis Damage Index).

6. Wszyscy pacjenci z MZSM powinni mieć możliwość zarejestrowania się w rejestrze zapalenia mięśni krajowym lub międzynarodowym (np. Euromyositis). 
7. Pacjenci z grupy wysokiego ryzyka wymagają natychmiastowego (pilnego) skierowania do specjalistycznego ośrodka.

Pacjenci wysokiego ryzyka, gdy występuje:

- ciężka niepełnosprawność, określona przez niezdolność do wstania z łóżka;

— wynik CMAS < 15 lub wynik MMT8 < 30 pkt.;

— obecność aspiracji lub dysfagii (niemożność połykania);

- zapalenie naczyń przewodu pokarmowego (gastrointestinal vasculitis) określone przez obrazowanie lub obecność krwawych stolców;

— zapalenie mięśnia sercowego;

- śródmiąższowa choroba płuc;

- zajęcie CSN (określana jako zaburzenia świadomości lub drgawki);

- owrzodzenie skóry;

- konieczność leczenia na oddziale intensywnej terapii;

— wiek $<1$ roku życia.

\section{ZALECENIA DOTYCZACE DIAGNOSTYKI}

\section{A. Zalecenia ogólne}

W przypadku braku objawów skórnych i/lub braku odpowiedzi zgodnie z oczekiwaniami na zastosowane leczenie, należy rozważyć alternatywne rozpoznanie, $\mathrm{w}$ tym miopatie i dystrofie metaboliczne lub mitochondrialne.

U każdego pacjenta, u którego rozpoznano MZSM, należy wziąć pod uwagę poniższą listę badań:

- enzymy mięśniowe w tym CPK, LDH, ASPAT, ALAT, aldolaza (jeśli badanie jest dostępne);

- MF + obraz;

- OB i białko C-reaktywne (CRP, C-reactive protein);

- przeciwciała mięśniowo swoiste dla zapalenia mięśni i przeciwciała związane z miopatią;

- czynność nerek i testy czynnościowe wątroby;

- panel badań w kierunku infekcji (do diagnostyki różnicowej);

- badania alternatywnych przyczyn układowych miopatii, w tym zaburzeń endokrynologicznych (zwłaszcza funkcji tarczycy), zaburzeń elektrolitowych, niedoboru witaminy $\mathrm{D}$;

- dalsze badania dotyczące miopatii metabolicznej/mitochondrialnej (szczególnie w przypadku braku zmian skórnych/nietypowego obrazu klinicznego;
- paskowy test moczu (z dalszą oceną, jeśli wynik dodatni dla białka);

- kapilaroskopia;

- ECHO i EKG;

- testy czynnościowe płuc (spirometria oraz RTG, HRCT);

- MRI mięśni (+ USG mięśni, ilościowe);

- EMG (szczególnie w przypadku podejrzenia neuropatii (zaburzeń połączenia nerwowo-mięśniowego);

- biopsja mięśnia (zwłaszcza przy braku zmian skórnych/nietypowej prezentacji);

- MRI mózgu, jeśli podejrzewa się zajęcie CSN (objawy neurologiczne);

- USG jamy brzusznej.

B. Zalecenia szczegółowe Ocena zajęcia mięśni

- Zarówno siła i funkcja mięśni powinny być testowane podczas diagnostyki i leczenia za pomocą formalnie zwalidowanych testów, takich jak MMT8 i CMAS.

- MRI może być użyteczne w diagnostyce MZSM.

- MRI można wykorzystać do monitorowania aktywności choroby.

- Gdy jest stosowany, MRI powinny być wykonywane przez określone protokoły, które zwiększają wykrywanie zapalenia mięśni, takie jak T2 zależne/sekwencja STIR.

- MRI powinien być interpretowany przez eksperta radiologa.

- Biopsję mięśnia należy wykonać we wszystkich przypadkach, w których prezentacja MZSM jest nietypowa; w szczególności w przypadku braku objawów skórnych.

- Jeśli wykonano biopsję mięśnia w celu rozpoznania MZSM, należy użyć znormalizowanego narzędzia do oceny biopsji w celu oceny nasilenia zmian histologicznych.

- W celu określenia cech stanu zapalnego w biopsji mięśni w MZSM wymagana jest ekspertyza histopatologiczna.

- Podczas wykonywania biopsji mięśnia nie ma wystarczających dowodów, aby zalecić biopsję igłową w przeciwieństwie do otwartej biopsji u dzieci.

- W przypadkach, w których nie jest możliwe wykonanie MRI lub biopsji mięśnia, podwyższone echogram mięśnia w ultrasonografii mięśni (wykonywane przez doświadczonego badacza) może wskazywać na zapalenie mięśni.

- Funkcja połykania powinna być formalnie oceniona u każdego pacjenta, ocena może obejmować ocenę terapii mowy i funkcji ję- 
zyka, badania fluoroskopowe/wideo/RTG $\mathrm{z}$ kontrastem.

- Należy rozważyć EMG lub przewodnictwo nerwowe, aby odróżnić miopatię od neuropatii, gdy rozpoznanie MZSM jest niepewne.

- EMG nie wykrywa rzetelnie miopatii metabolicznych i wymaga dalszej analizy, jeśli podejrzewa się taką diagnozę.

\section{OCENA ZAJĘCIA SKÓRY}

- Do diagnostyki JDM należy zastosować ocenę naczyń włosowatych w kapilaroskopii.

- W momencie rozpoznania lub zaostrzenia choroby zalecana jest standaryzowana ocena kapilaroskopowa, podczas badania kontrolnego należy regularnie wykonywać ocenę naczyń włosowatych.

- Do pomocy w diagnozowaniu MZSM należy użyć formularza CAT.

- Formularza CAT należy używać do monitorowania aktywności choroby skóry w czasie.

- Narzędzia do pielęgnacji i oceny skóry mogą obejmować DAS, MITAX lub CAT.

\section{OCENA ZAJĘCIA PŁUC}

- Wszyscy pacjenci z JDM powinni mieć ocenę zajęcia płuc w momencie diagnozy.

- Ocena powinna obejmować testy czynnościowe płuc, DLCO. Jeśli testy czynnościowe płuc wskazują na śródmiąższową chorobę płuc, potrzebne są dalsze badania (RTG/HRCT).

\section{OCENA ZAJĘCIA SERCA}

- Wszyscy pacjenci z MZSM powinni mieć ECHO i EKG w momencie rozpoznania.

- Pacjenci ze szczególnym ryzykiem dysfunkcji serca powinni mieć powtarzaną ocenę kardiologiczną.

- Czynniki ryzyka obejmują nadciśnienie, wysoką aktywność choroby w rok po postawieniu diagnozy, długotrwałe leczenie GKS lub przewlekłą aktywną chorobę.

\section{OCENA ZWAPNIEŃ}

- U wszystkich pacjentów z MZSM należy leczyć kalcynozę.

- Zwykłe radiogramy mogą być użyte do oceny wapnienia.

\section{AUTOPRZECIWCIAŁA I BIOMARKERY}

- Zalecane jest stosowanie enzymów mięśniowych (CPK, LDH, AST) do diagnostyki i monitorowania przebiegu MZSM, chociaż należy uznać, że enzymy mięśnio- we mogą być w normie pomimo aktywności choroby.

- Pomiar stężenia czynnika von Willebranda nie dostarcza żadnych dodatkowych informacji przydatnych w diagnostyce MZSM.

- Nie ma znaczącej korzyści diagnostycznej uzyskanej z oznaczania ANA w MZSM.

- Zalecane są dalsze badania walidacyjne w celu zdefiniowania zastosowania bardziej czułych biomarkerów w MZSM.

- Należy rozważyć wykonanie badań autoprzeciwciał swoistych dla miopatii (takich jak anty-TIF 1- $\gamma$ (p155), anty-NXP2/ (p140/MJ), anty-MDA5 i anty-SRP) (jeśli są dostępne).

- U pacjentów z zespołem nakładania należy rozważyć wykonanie przeciwciał towarzyszących zapaleniu mięśni, takich jak anty-PmScl, anty-U1-RNP, anty-La (,SSB”), anty-Ro (,SSA”) i anty-Sm może być pomocny w wyjaśnić diagnozę.

\section{REKOMENDACJE DOTYCZACE LECZENIA}

- Należy zachęcać do ochrony przed słońcem, w tym rutynowego stosowania kremów z filtrami na obszarach narażonych na działanie słońca u pacjentów z MZSM.

- Podczas leczenia pacjentów z MZSM szczególnie ważne jest aktywne angażowanie fizjoterapeuty i specjalistycznej pielęgniarki w ramach zespołu wielodyscyplinarnego.

- Leczenie MZSM powinno obejmować bezpieczny i odpowiedni program ćwiczeń, monitorowany przez fizjoterapeutę.

- Zalecane jest stosowanie schematu indukcji w leczeniu nowych pacjentów z MZSM w oparciu o dużą dawkę GKS (doustnie lub dożylnie) w połączeniu z MTX.

- GKS w dużej dawce należy podawać ogólnoustrojowo doustnie lub dożylnie w umiarkowanie ciężkich postaciach MZSM.

- GKS w dużej dawce należy podawać dożylnie, jeśli istnieją obawy dotyczące wchłaniania przy podawaniu doustnym.

- Dawka GKS powinna zostać zredukowana, jeżeli pacjent wykazuje poprawę kliniczną.

- Dodanie MTX lub cyklosporyny A prowadzi do lepszej kontroli choroby niż leczenie tylko GKS; profile bezpieczeństwa sprzyjają połączeniu MTX i prednizolonu.

- MTX należy rozpoczynać od dawki 15$20 \mathrm{mg} / \mathrm{m}^{2} /$ tydzień (maksymalna bezwzględna dawka $40 \mathrm{mg} /$ tydzień), korzystniejsze są 
efekty przy podawaniu podskórnym w momencie wystąpienia objawów choroby.

- Jeśli nowo zdiagnozowany pacjent ma niewystarczającą odpowiedź na leczenie, należy rozważyć intensyfikację leczenia w ciągu pierwszych 12 tygodni, po konsultacji $\mathrm{z}$ centrum eksperckim.

- IVIG mogą być użytecznym dodatkiem do leczenia opornej choroby, szczególnie gdy widoczne są cechy zajęcia skóry.

- MMF może być użyteczną terapią zajęcia mięśni i skóry (także kalcynozy).

- Aktualny stan zajęcia skóry odzwierciedla aktywną chorobę ogólnoustrojową i dlate- go powinna być leczona przez intensyfikację immunosupresji układowej.

- Miejscowo podawane GKS oraz preparaty zawierające takrolimus $(0,1 \%)$ mogą pomóc w zlokalizowanej chorobie skóry, szczególnie w objawowym zaczerwienieniu lub swędzeniu.

- U pacjentów, którzy nie tolerują MTX, należy zmienić na inny DMARD, w tym CsA lub MMF.

- W przypadku pacjentów z ciężką chorobą (takich jak zajęcie dużych narządów/rozległe owrzodzenia skóry) należy rozważyć dodanie cyklofosfamidu podawanego i.v.

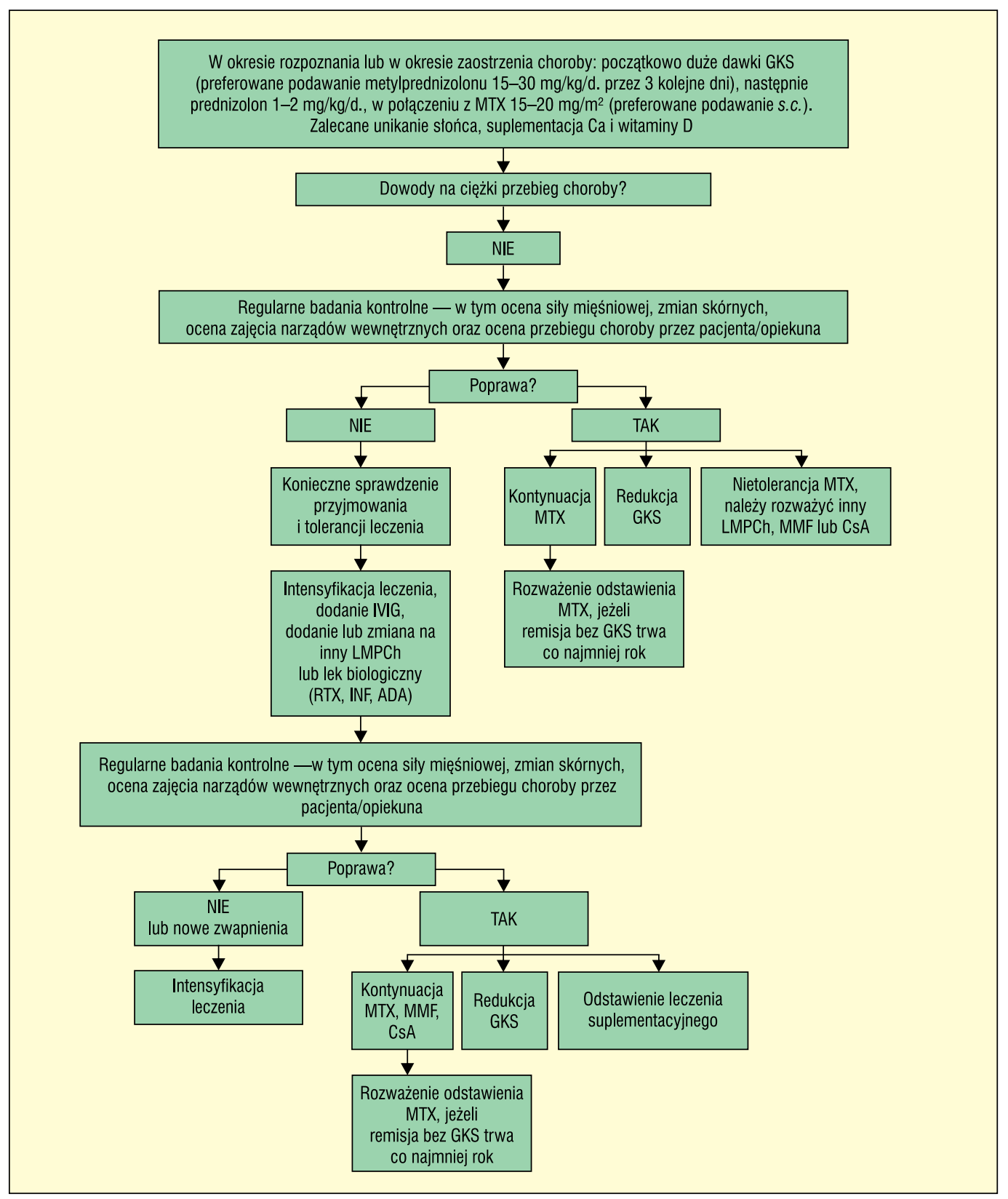

Rycina 1. Schemat leczenia łagodnej/umiarkowanej postaci choroby u nowo zdiagnozowanych oraz opornych na wstępne leczenie GKS pacjentów z młodzieńczym zapaleniem skórno-mięśniowym (MZSM) 


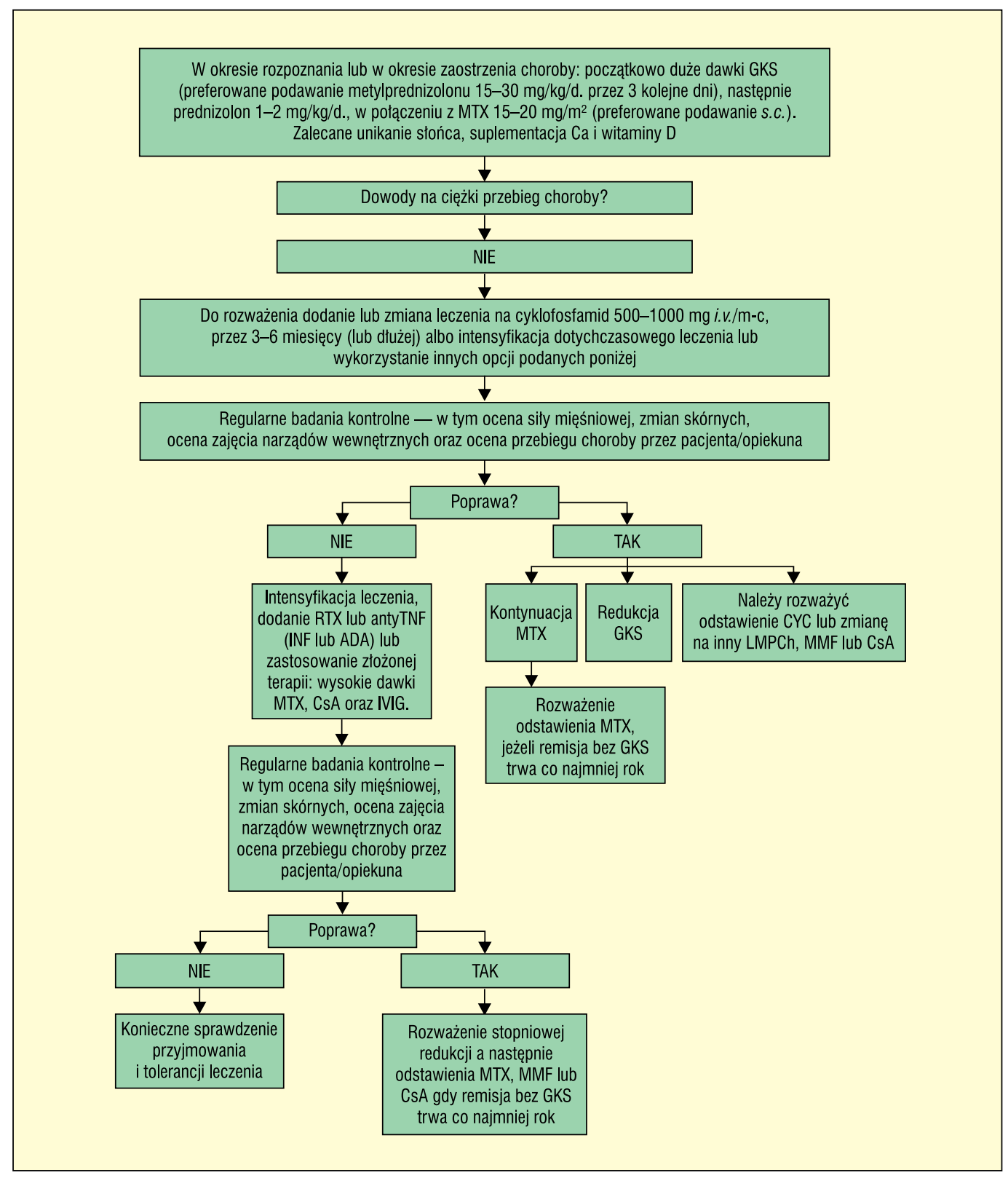

Rycina 2. Schemat leczenia ciężkiej postaci choroby u nowo zdiagnozowanych oraz w przypadkach nieskuteczności leczenia pacjentów chorujących na MZSM

- Terapie inhibitorami TNF można rozważać w chorobie opornej; INF lub ADA są preferowane w stosunku do ETN.

- W przypadku rozwijającego się lub utrwalonego wapnienia należy rozważyć intensyfikację leczenia immunosupresyjnego.

- Nie ma żadnych dowodów na to, kiedy można przerwać terapię; jednak można rozważyć wycofanie leczenia, jeśli odstawiono leczenie GKS i uzyskano remisję na MTX (lub alternatywnym DMARD) przez co najmniej rok.

- Deplecja limfocytów B (RTX, rytuxymab) może być traktowana jako terapia wspomagająca dla osób z oporną chorobą, lekarze powinni mieć świadomość, że rytuksymab może działać do 26 tygodni (ryc. 1, 2).

\section{PODSUMOWANIE}

Ścisłe monitorowanie stanu zdrowia i dobrego samopoczucia pacjentów przez doświadczony, wielodyscyplinarny zespół ma zasadnicze znaczenie dla dobrego wyniku klinicznego. Najnowsze doniesienia podkreślają znaczenie wczesnego, agresywnego leczenia MZSM, ponieważ wiąże się to z lepszą kontrolą przebiegu choroby. Ze względu na niewielką częstość zachorowań, konieczne są długookresowe wieloośrodkowe badania 
kontrolne, aby wyjaśnić ryzyko powikłań, współpraca międzynarodowa ma kluczowe znaczenie. Potrzebne są dalsze badania i opracowania dotyczące aktywności choroby, jej przebiegu oraz zagrażających powikłań i długotrwałych następstw choroby.

Podsumowując, inicjatywa SHARE opiera się na opiniach ekspertów opartych na najlepszych dostępnych dowodach i zawiera zalecenia dotyczące diagnostyki, leczenia oraz całościowej opieki nad pacjentami z MZSM, mając na celu poprawę wyników leczenia pacjentów z MZSM w całej Europie. Inicjatywa SHARE dotyczy także innych chorób reumatycznych u dzieci, będąc platformą bieżącej współpracy na terenie wszystkich krajów europejskich. Obecnie ważne będzie poszerzenie dyskusji i przetestowanie akceptacji przedstawionych rekomendacji dla szerokiej społeczności europejskich reumatologów dziecięcych. 